\title{
HUMAN RIGHTS AND LABOR LAW
}

\author{
DIREITOS HUMANOS E DIREITO DO TRABALHO
}

\section{DERECHOS HUMANOS Y DERECHO DEL TRABAJO}

\section{Gilberto Stürmer ${ }^{1}$}

Licença CC BY:

Artigo distribuído sob os termos Creative Commons, permite uso e distribuição irrestrita em qualquer meio desde que o autor credite a fonte original.

\section{(i)}

Abstract: This text addresses the right to work, and labor law based on the Protocol of San Salvador, which is part of the American Convention on Human Rights, also called the Pact of San José, Costa Rica. The aims of Labor and labor legislation within the scope of human rights, and also in Brazilian constitutional system as part of the fundamental rights and guarantees, is to achieve a Democratic State of Law and social justice, which are the basis of a fair and fraternal society. This investigation is linked to positive or negative social impact of the regulations on the right to work and labor law, both within the domestic legal system (such as rights and fundamental principles), and internationally, as human rights (especially in the Protocol of San Salvador). This work therefore aims to demonstrate that the regulation of the right to work and labor law is part of a broad social context of rights.

Key words: Human Rights, Labor Law, Social Law, Protocol of San Salvador.

Resumo: Este texto trata do direito ao trabalho e das leis trabalhistas baseadas no Protocolo de San Salvador, o qual faz parte da Convenção Americana de Direitos Humanos, também chamada de Pacto de San José, Costa Rica. Os objetivos do trabalho e da legislação trabalhista no âmbito dos direitos humanos, e também no sistema constitucional brasileiro, como parte dos direitos e garantias fundamentais, são alcançar um Estado de Direito Democrático e a justiça social, que são a base de uma sociedade justa e fraterna. Esta pesquisa está ligada ao impacto social positivo ou negativo das regulações do direito ao trabalho e da legislação trabalhista, tanto no sistema jurídico doméstico (como direitos e princípios fundamentais), quanto internacionalmente, como direitos humanos (especialmente no Protocolo de San Salvador). Este trabalho, portanto, visa demonstrar que a regulamentação do direito ao trabalho e do direito do trabalho faz parte de um amplo contexto social de direitos. 
Palavras-chave: Direitos humanos, Direito do trabalho, Direito social, Protocolo de San Salvador. Salvador.

Resumen: Este texto trata del derecho al trabajo y de las leyes laborables basadas en el Protocolo de San Salvador, el cual forma parte de la Convención Americana de Derechos Humanos, también llamada de Pacto de San José, Costa Rica. Los objetivos del trabajo y de la legislación laboral en el ámbito de los derechos humanos, y también en el sistema constitucional brasileño, como parte de los derechos y garantías fundamentales, son alcanzar un Estado de Derecho Democrático y justicia social, que son la base de una sociedad justa y fraterna. Esta investigación está relacionada al impacto social positivo o negativo de las regulaciones del derecho al trabajo y de la legislación laboral, tanto en el sistema jurídico doméstico (como derechos y principios fundamentales), como internacionalmente, como derechos humanos (especialmente en el Protocolo de San Salvador). Este trabajo, por tanto, visa demostrar que la reglamentación del derecho al trabajo y del derecho del trabajo forman parte de un amplio contexto social de derechos.

Palabras clave: Derechos humanos, Derecho del trabajo, Derecho social, Protocolo de San Salvador. Salvador.

INTRODUCTION

This paper focuses on International Labor Law and its legal aspects, such as the historical aspects of internationalization of labor law and social rights, international documents of International Labor Organization and other important agencies dealing with this matter.

This text addresses the Right to Work in the Additional Protocol of the American Convention on Human Rights, in terms of economic, social and cultural rights, through its Protocol of San Salvador.

The Protocol of San Salvador covers the States Parties to the American Convention on Human Rights, also called the Pact of San José, Costa Rica.

The purpose of the protocol is to reaffirm the purpose of consolidating a system of personal liberty and social justice in Latin America, based on respect for the essential rights of mankind.

The Protocol of San Salvador recognizes that the essential rights of mankind do not derive from the fact that a person is a national of a given State, but from the fact that these rights are based on attributes of human beings. For this 
Novos Estudos Jurídicos

reason, it justifies international protection as being of a conventional, supporting or complementary nature to that offered by the American States domestic law.

The relationship between the validity of economic, social and cultural rights and that of civil and political rights is considered, since the different categories of law constitute an indissoluble whole, based on the recognition of dignity of the human being, for which protection and permanent promotion are required, aiming at achieving its full validity. Thus, the violation of some rights on the pretext of accomplishing others can never be justified

The Protocol recognizes the benefits of fostering and developing cooperation between States and international relations.

This paper, as already mentioned, is based on the provisions involving the Right to Work and Labor Law, which is discussed below. First, it examines the Brazilian constitutional system before going on to examine the Protocol.

\section{HUMAN RIGHTS AND THE UNITED NATIONS}

According to the Universal Declaration of Human Rights, "All human beings are born free and equal in dignity and rights. Gifted with reason and conscience, they must act towards one another in a spirit of brotherhood "(Article 1).

Human Rights are the basic rights and freedoms of all human beings. They comprise:

- a) civil and political rights (life, property, thought, expression, belief, nationality and others);

- b) economic, social and cultural rights (work, education, health, social security, housing, etc.);

- c) diffuse and collective rights (peace, progress, self-determination of peoples, environmental, consumer, digital inclusion, etc.) 


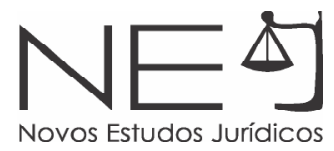

PEREZ LUÑO² conceptualizes Human Rights as follows:

A set of capabilities and institutions that at every historical moment fulfill the requirements of human dignity, freedom and equality, which must be positively recognized by the legal systems at national and international level.

According to the Universal Declaration of Human Rights and the American Convention on Human Rights, the ideal of free human being, free from fear and misery, can only be accomplished if conditions are created that allow each person to enjoy their economic, social and cultural rights, as well as their civil and political rights. While fundamental economic, social and cultural rights have been recognized in previous international instruments, both universal and regional, it is very important that these rights be reaffirmed, developed, perfected and protected, in order to consolidate the democratic regime representative of government in America, based on full respect of the rights of individuals, as well as the right of their peoples to development and self-determination, and the right to freely dispose of their riches and natural resources.

Finally, the preamble to the Protocol of San Salvador considers that the American Convention on Human Rights establishes that additional projects and protocols to this Convention (Protocol of San Salvador) may be submitted for consideration of States Parties at the General Assembly of the Organization of American States, with the aim of gradually including other rights and freedoms in its regime of protection.

The first 20 Articles of the Protocol cover the following topics: Obligation to Adopt Measures; Obligation to Enact Domestic Legislation; Obligation of Nondiscrimination; Inadmissability of Restrictions; Scope of Restrictions and Limitations; Right to Work; Just, Equitable and Satisfactory Conditions of Work; Trade Union Rights; Right to Social Security; Right to Health; Right to a Healthy Environment; Right to Food; Right to Education; Right to the Benefits of Culture; Right to the Formation and the Protection of Families; Rights of Children; Protection of the Elderly; Protection of the Handicapped; Means of Protection; and Reservations.

2 PEREZ LUÑO, Antonio Enrique. Derechos Humanos, estado de Derecho y Constitución. $3^{\mathrm{a}}$ ed. Madri: Teccnos, 1990. p. 48). 
Novos Estudos Jurídicos

Finally, it was opened for Signature, Ratification or Accession: entry into Effect and finally (Article 21) and the Inclusion of Other Rights and Expansion of those Recognized (Article 22).

The Protocol of San Salvador was signed in El Salvador on November 17, 1988 and was ratified by Brazil on August 21, 1996.

\section{RIGHT TO WORK, LABOR LAW AND TRADE UNION LAW IN BRAZIL}

The Federative Republic of Brazil Constitution of October 5, 1988, in its preamble, highlights the importance of international relations.

The text of the Brazilian Constitution of 1988 shows, right from the outset, in its Preamble, the value of international relations for the country:

We the representatives of the Brazilian people, convened the National Constituent Assembly, to institute a democratic state destined to ensure the exercise of social and individual rights, liberty, security, well-being, development, equality and justice as supreme values of a fraternal, pluralist and unprejudiced society, founded on social harmony and committed, in the internal and international ${ }^{3}$ orders, to the peaceful solution of disputes, promulgate, under the protection of God, the following CONSTITUTION OF THE FEDERATIVE REPUBLIC OF BRAZIL.

The Constitution also emphasizes, among other equally important principles, the social values of labor and free enterprise. It is clear that in the current constitutional model, "labor" and "free enterprise" go hand-in-hand. There is no doubt that in modern Labor Law, social and economic complement each other.

Labor appears again in Article 6, within the Chapter on social rights.

The social rights are the Right to Work and Labor Law. In the lesson of Uadi Lammêgo Bulos,

3 Author's emphasis.

... work, in the light of what is established by prescriptive language of the constituent legislator, means a way of making a living lawfully, through the performance of a paid productive activity. In this particular, it resembles employment. In fact, what was sought, in theory, was a 


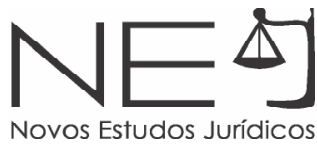

response against unemployment, discontent, hunger, misery, violence and other evils embedded in the structure of capitalist states. ${ }^{4}$

In this context, the Right to Work is clear.

Labor Law, i.e. the rules related to the legal employment relationship, were listed for the first time as fundamental social rights in the Brazilian Constitution 1988, in its Article 7, which addresses the rights of urban and rural workers in thirty-four items plus a sole paragraph. It lists the following rights: protection of employment against arbitrary dismissal, and severance pay ${ }^{5}$; unemployment insurance ${ }^{6}$; Guarantee Fund for the length of service ${ }^{7}$; a national uniform minimum wage; a salary floor; irreducibility of salaries or wages; minimum wage guarantees; a thirteenth-month salary (popularly known in Brazil as the "Christmas bonus"; higher remuneration for nighttime work; wage protection; participation in profits or results ${ }^{9}$; family allowance for dependents of the lower income worker ${ }^{10}$; normal working hours not to exceed eight hours per day and forty-four hours per week; a workday week of six hours for work performed in continuous shifts; paid weekly paid rest ${ }^{11}$; a payscale for overtime; annual paid vacations at a rate of at least one-third higher than the normal pay; maternity leave; paternity leave; protection of the job market for women; advance notice of dismissal proportional to the length of service ${ }^{12}$; reduction of risks inherent to the job (more recently covered by Environmental Labor Law); additional remuneration for strenuous, unhealthy or dangerous work ${ }^{13}$; retirement pension; free assistance for children and dependents; recognition of collective bargaining accords and agreements; protection because of automation; occupational accident insurance; a cause of action for amounts due from employment relationships; prohibition of any

$4 \quad$ Federal Constitution Annotated. São Paulo: Saraiva, 6a ed., 2005, p. 425.

5 Item I, of article 7, calls for a complementary law that does not exist until the moment this article was written.

6 Law $n^{\circ} 7.998$, of $11 / 01 / 1990$.

7 Law $n^{\circ} 8.036$, of $11 / 05 / 1990$.

8 Law $n^{\circ} 4.090$, of $13 / 07 / 1962$.

9 Law $n^{\circ} 10.101$, of $19 / 12 / 2000$.

10 Law $n^{\circ} 4.266$, of $03 / 10 / 1963$.

11 Law no. 605 of 05/01/1949.

12 Proportionality of prior notice as employee workers right only came in 2011: Law no. 12,506, of 11/26/2011.

13 Additional payment for unhealthy work is regulated by Article 192 of CLT (Labor Laws Consolidation) and additional danger, by Article 193 of the same law. There is no general regulation on additional suffering. Sporadic laws and collective norms of categories define suffering as work that, although it does not cause physical damage to the worker, can make his professional activity more suffered from the mental point of view. 
Novos Estudos Jurídicos

difference in pay due to sex, age, color or marital status; prohibition against discrimination against handicapped workers; prohibition of distinction among manual, technical and intellectual work; prohibition of nighttime, dangerous or unhealthy work for minors; and equal rights for occasional workers. The Sole Paragraph lists the rights of domestic workers, enhanced by Constitutional Amendment No. 72, dated April 2, 2013.

Article 8 lists trade union rights, such as freedom to form syndical associations, creation of trade union entities, prerogative of categorical representation and collective labor bargaining by unions, non-compulsory union membership, right of retirees to participate in trade union life, and provisional stability of the union leader.

Item II, which maintains trade union unity and item IV which, in addition to creating confederation contribution, maintains the contribution of the trade union, are out of context in Article 8.

According to Articles 2 and 3 of Convention No. 87 of the International Labor Organization (ILO) of June 171948 (according to the ILO itself, its main international treaty - not by chance, has not been ratified by Brazil until today), which establishes the concept of trade union freedom as a bilateral concept (both employees and employers are holders of said right), there can be no distinction and no prior authorization for employees and employers to form their trade union organizations. More: there can be no interference from anyone in the elaboration of articles of association and administrative regulations, election of representatives, administrative organization and formulation of action programs. Authorities should refrain from limiting such rights.

There is no doubt that union unity and compulsory trade union are harmful to trade union freedom ${ }^{14}$. Freedom of association is, according to renowned international authors, a human and fundamental right.

Uruguayan professor of Labor Law, Oscar Ermida Uriarte, who died in 2011, states, in one of his many writings on the subject, that:

14 On freedom of association, among others, see Gilberto Stürmer, "Freedom of association in the Constitution of the Federative Republic of Brazil of 1988 and its relation to ILO Convention No. 87. Porto Alegre: Livraria do Advogado Editora, 2007. 


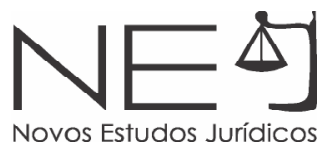

It is absolutely out of question that freedom of association is one of the most recognized human rights or fundamental rights in constitutions and human rights covenants and declarations. But there is more to it. Freedom of association is no longer a human or fundamental right, but it is a prerequisite or condition of power and exercise of other rights. Using the buzzword, one could say that it is <the right to have rights>, a right that generates or creates other rights. ${ }^{15}$

For the Spanish Antonio Ojeda Avilés, "freedom of association is the fundamental right of workers to stably come together to participate in grouping productive relations ${ }^{16}$."

The Argentine Carlos Alberto Etala defines freedom of association as:

The set of rights, powers, prerogatives and immunities granted by constitutional, international and legal norms to workers and organizations voluntarily constituted by them, in order to guarantee the development of licit actions aimed at the defense of their interests and improvement of their living conditions and job. ${ }^{17}$

Finally, the Italian Giuno Giugni, addressing the theme, ${ }^{18}$ refers to ILO Convention 87, stating that "it particularly establishes that workers and employers, without discrimination of any kind, have the right to form and join trade union organizations without prior authorization of the State."

Article 9 of Brazilian Constitution also establishes the right to strike as a fundamental right, extending it to public servants (article 37, section VII. The rights of representation are contained in articles 10 and 11.

The Brazilian Constitution also addresses labor from the economic and financial perspective (based on the valuation of human work and free initiative, with the principles of private property, free competition, pursuit of full employment, and favorable treatment for small size companies (Article 170, items II, IV, VIII and IX). The social function of property is linked to the observance of provisions that regulate labor relations (Article 186, subsection II, of the Constitution of Republic).

15 Óscar Ermida Uriarte. Crítica de la libertad sindical, in Revista de La Faculdad de Derecho de la Pontifícia Universidad Catolica del Perú nº 68, 2012, págs. 33-61.

16 Antonio Ojeda Avilés, Compendio de Derecho Sindical. Madrid: Tecnos, 1998, p. 34;

17 Carlos Alberto Etala, Derecho Colectivo del Trabajo, Buenos Aires: Astrea, $2^{\mathrm{a}}$ edición, 2007, p.61.

18 Gino Giugni, Direito Sindical.São Paulo: LTr, 1991, p. 48. 
Novos Estudos Jurídicos

The social order is based on the primacy of labor (Article 193 of Constitution). The environment is also highlighted, including labor ${ }^{19}$ (Article 200, item VIII, of Federal Constitution).

After having seen in details the right to work and labor law, and trade union rights in the Brazilian constitutional system, we will examine the Protocol of San Salvador.

\section{RIGHT TO WORK AND THE PROTOCOL OF SAN SALVADOR}

Article 6 of the Protocol of San Salvador is divided into two parts.

The first part states that every person has the right to work, which includes the opportunity to obtain the means to lead a decent and honorable life through conducting a legal, freely chosen or accepted activity.

Emphasis is placed on the right to work as a human right ${ }^{20}$ (international context) and a fundamental right ${ }^{21}$ (internal context of each legal system).

In the second part of article 6 , there is reference to the commitment of States Parties to adopt measures that will guarantee full effectiveness of the right to work, especially measures related to achieving full employment, vocational guidance and development of technical and vocational training projects, particularly for the disabled. In this section, the Protocol further states that States Parties also undertake to implement and strengthen programs to support adequate care of family, so that women can have a real possibility of exercising their right to work.

The Democratic State of Law existing in Brazil assures said rights in the Brazilian Constitution, as already seen.

This approach is highlighted in the context of fundamental social rights, economic order and social order.

19 Work environment comprises health, hygiene and safety standards, listed in articles 154 to 201 of CLT.

20 According to Uadi Lammêgo Bulos, this terminology is characteristic of declarations of universal rights, seeking to reinforce the idea that only mankind is the holder. Ob. Cit., P. 107.

21 As seen in previous topic, the Constitution of the Federative Republic of Brazil of 1988 uses this expression. 


\section{FAIR, EQUITABLE AND SATISFACTORY CONDITIONS OF WORK AND THE PROTOCOL OF SAN SALVADOR}

What are fair, equitable, and satisfactory conditions of work?

In the Protocol, the right to work referred to above presupposes that everyone enjoys the same right, under fair, equitable and satisfactory conditions.

Therefore, States Parties should ensure the following rights in their domestic law:

a) Remuneration which at least, guarantees to all workers decent and honorable living conditions for themselves and their families, and equal pay for equal work without any distinction.

In addition to the subsections of article 7 of Brazilian Constitution dealing with minimum wage (item IV) and wage floor (item V), both public policies for valuation of minimum wage, when collective bargaining instruments of various categories have sought this right.

b) Right of all workers to follow their vocation and dedicate themselves to the activity that best meets their expectations and change jobs according to the respective national regulations.

This right is in the scope of what is considered ideal, since in Brazil, as in other countries that adopt the Protocol of San Salvador, maintenance of current employment and, consequently, the search of alimentary nature of the salary are in first place.

c) Worker's right to promotion or advancement at work, for which their qualifications, competence, probity and length of service shall be considered.

These criteria are adopted in Brazil in special legislations, collective norms and internal regulations. 
d) Stability of workers in their jobs, according to characteristics of industries and professions and the causes of fair dismissal. In cases of unjustified dismissal, the worker shall be entitled to compensation or reinstatement in employment or to any other benefits provided for by Brazilian law.

As a general rule, already mentioned, protection against arbitrary dismissal or without just cause, provided for in item I, of article 7, of the Constitution, depends on regulation by a complementary law, which has not yet been established. There is, however, provision for compensation for unmotivated dismissals (Article 10, I, of Transitional Constitutional Provisions Act of 1988 Constitution).

There are possibilities of provisional stabilities (guarantees in employment), such as for the union leader (Article 8, VIII, of Constitution), elected member of the Internal Commission for Accident Prevention (Article 10, II, 1, ADCT, Constitution), and pregnant women (Article 10, II, b, ADCT of 1988 Constitution), as well as other infra-constitutional hypotheses.

e) Safety and hygiene at work.

As already mentioned, in addition to being provided for in the Federal Constitution, the matter is regulated in CLT (Labor Law Consolidation).

f) Prohibition of night work or activities that are unhealthy or dangerous for persons under 18 years of age and, in general, any work that may endanger their health, safety or moral. In the case of children under the age of 16 , the working day shall be subject to provisions on compulsory education and, in no case, may constitute an impediment to school attendance or limitation to benefit from formal education received.

Command concerning protection of labor by minors is provided for in the Brazilian Constitution, Labor Law Consolidation, and Statute of Children and Adolescents (Law No. 8,069, July 13, 1990).

g) Reasonable limitation of working hours, both daily and weekly. Journeys will be of shorter duration when dealing with dangerous, unhealthy or nighttime jobs. 
Brazilian law establishes eight hours of work per day and forty-four hours per week (Article 7, item XIII, of Brazilian Constitution). There is also a limitation on overtime (articles 59 and 61 of the CLT), and nighttime work (CLT Article 73). Unhealthy work is governed by Article 192 of the CLT, combined with Regulatory Rule 15, of Ordinance No. 3.214, 1978, of the Ministry of Labor and Employment. Hazardous work, in addition to article 193 of the CLT, is governed by sporadic laws and by Regulatory Rule No. 16 of the aforementioned Ordinance.

h) Rest, enjoyment of free time, paid vacations, and remuneration for national holidays.

In Brazil, rest and official holidays are remunerated (article 7, item XV, of Constitution and Law no. 605/1949), and vacations are paid at a rate of at least one-third higher than the normal pay (article, 7, item XVII, of the Constitution and CLT article 129).

Finally, the Brazilian legal system, especially after the entry into force of the current Brazilian Constitution, seeks to regulate working conditions, which, as mentioned above, gives rise to Labor Law.

\section{TRADE UNION RIGHTS AND THE PROTOCOL OF SAN SALVADOR}

Article 8 of the Protocol, which is divided into three parts, deals with trade union rights.

In the first part, it states that States Parties shall ensure:

a) The right of workers to organize unions and join the union of their choice for the purpose of protecting and promoting their interests. As an extension of that right, the States Parties shall permit trade unions to establish national federations or confederations, or to affiliate with those that already exist, as well as form international trade union organizations and to affiliate with that of their choice. States Parties shall permit trade unions, federations and confederations to function freely. 
This command, reiterating ILO Convention 87, protects the freedom of association which, in Brazil, as mentioned above, still has restrictions, particularly when it comes to the rules of trade union unity and compulsory trade union contribution.

b) Right to strike.

The right to strike is recognized in Brazil as a fundamental right (Articles 9 and 37, item VII, of the Constitution) and is regulated by Law No. 7.783, of June 28, 1989.

In the second part of article 8, the Protocol of San Salvador states that "the exercise of the rights set forth above may be subject only to restrictions established by law, provided that such restrictions are characteristic of a democratic society and necessary for safeguarding public order or for protecting health or morals, and the rights or freedoms of others. Members of the armed forces and the police and of other essential public services shall be subject to limitations and restrictions established by law.

Federal Constitution, CLT and sparse laws, especially the Strike Law, establish these limits.

Finally, part 3 of Article 8 states that "no one may be compelled to belong to a trade union".

This command, in addition to general provisions of subsections XVI to XXI of article 5, is specifically contained in Article 8, paragraph $V$, of the Constitution.

\section{FINAL CONSIDERATIONS}

This paper aims to contribute to the theme of International Labor Law. It seeks to address both right to work and labor law as human and fundamental rights provided for in the Brazilian legal system, as well as various rules on the subject contained in the Conventions of the International Labor Organization, the Additional Protocol to the American Convention on Human Rights, and in issues of Economic, Social and Cultural Rights, in the Protocol of San Salvador. 


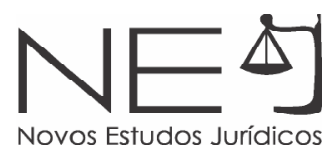

The right to work and labor law are human rights. This is why it is addressed in international treaties, and stated as fundamental rights in the Brazilian constitutional system. Moreover, labor and the right to engage in free enterprise are fundamental principles of the Democratic Rule of Law.

Concerned with the American social situation, the Inter-American Commission on Human Rights and States Parties to the American Convention on Human Rights, the so-called Pact of San Jose, Costa Rica sought to go beyond national domestic regulations, establishing genuine protections within the international scope.

\section{REFERENCES}

AVILÉS, Antonio Ojeda. Compendio de Derecho Sindical. Madrid: Tecnos, 1998.

BULOS, Uadi Lammêgo. Constituição Federal Anotada. São Paulo: Saraiva, 6a edição, 2005.

CHIARELLI, Carlos Alberto. O Trabalho e o Sindicato - Evolução e Desafios. São Paulo: LTr, 2005.

CUEVA, Mário de la. Panorama do Direito do Trabalho. (tradução de Carlos Alberto Gomes Chiarelli). Porto Alegre: Sulina, 1965.

ERMIDA URIARTE, Óscar. Crítica de la libertad sindical, in Revista de la Faculdad de Derecho de La Pontifícia Universidad Católica del Perú n 68, 2012, p. 33-61.

ETALA, Carlos Alberto. Derecho Colectivo del Trabajo. Buenos Aires: Astrea, $2^{\mathrm{a}}$ edición, 2007.

GIUGNI, Gino. Direito Sindical. São Paulo: LTr, 1991.

GUERRA FILHO, Willis Santiago. Processo Constitucional e direitos fundamentais. São Paulo: Celso Bastos Editor, 1999.

GUERRERO, Euquerio. Manual de Derecho Del Trabajo. México: Porrúa, 13a edição, 1983.

HOBSBAWM, Eric J. Os Trabalhadores - Estudos sobre a História do Operariado. São Paulo: Paz e Terra, 2000.

LAIMER, Adriano Guedes. O Novo Papel dos Sindicatos. São Paulo: LTr, 2003.

MAGANO, Octávio Bueno. Manual de Direito do Trabalho - Volume III. São Paulo: LTr, 1984.

MANGLANO, Carlos Molero. Derecho Sindical. Madrid: Editorial Dykinson, 1996.

MARTINS, Sergio Pinto. Comentários à CLT. São Paulo: Atlas, 17ª edição, 2013. 
OLEA, Manuel Alonso. Introducción al Derecho del Trabajo. Madrid: Civitas, 5a edición, 1994. PEREZ LUÑO, Antonio Enrique. Derechos Humanos, estado de Derecho y Constitución. $3^{\text {a }}$ ed. Madri: Teccnos, 1990.

ROBORTELLA, Luiz Carlos Amorim. O Moderno Direito do Trabalho. São Paulo: LTr, 1991.

RODRIGUEZ, Américo Plá. Princípios de Direito do Trabalho. São Paulo: LTr, 1996.

ROMITA, Arion Sayão. Direito do Trabalho - Temas em Aberto. São Paulo: LTr, 1998. . Direitos Fundamentais nas Relações de Trabalho. São Paulo: LTr, 2005.

RUSSOMANO, Mozart Victor. Princípios Gerais de Direito Sindical. Rio de Janeiro: Forense, $2^{\mathrm{a}}$ edição, 1998.

SARLET, Ingo Wolfgang. A Eficácia dos Direitos Fundamentais. Porto Alegre: Livraria do Advogado Editora, 1998.

STÜRMER, Gilberto. A liberdade sindical na Constituição da República Federativa do Brasil de 1988 e sua relação com a Convenção 87 da Organização Internacional do Trabalho. Porto Alegre: Livraria do Advogado Editora, 2007.

STÜRMER, Gilberto. Direito Constitucional do Trabalho no Brasil. São Paulo: Atlas, 2014. 